\title{
The benefits of inclusive education: new challenges for university teachers
}

\author{
Alina Georgeta Mag ${ }^{1, *}$, Sandra Sinfield ${ }^{2}$, and Tom Burns ${ }^{2}$ \\ ${ }^{1}$ Lucian Blaga University of Sibiu, Faculty of Social and Human Sciences, Department for Teacher \\ Training, Calea Dumbravii Nr. 34, 550324, Sibiu, Romania \\ ${ }^{2}$ London Metropolitan University, London, N7 6PP, United Kingdom
}

\begin{abstract}
Inclusive education is a child's right, not a privilege. The amount of current attention given to children and to childhood is unprecedented. In a world affected by financial crises, attitudes about children's needs are very important. Recent years have seen innovations in the focus of research, as political moves that challenge the ways different children have been excluded and silenced. Inclusive education is a real and urgent need for all educational systems around the world. Inside our university, the Teachers Training Department needs to take serious measures to create a professional environment for all the students involved in the initial training for becoming teachers at all levels. This study reveals the interest and the planning of our trainers to develop their competencies for inclusive education, supported by new ways of international support with the professional involvement of two experts in university education from London Metropolitan University. We discovered that inclusive education is a serious priority, most of their courses and seminars need continue improvement in this area and their interest to develop new skills is high. We need to increase attention to our professional development as a factor that can contribute to a healthy society.
\end{abstract}

\section{Introduction}

The education system in the entire world is changing and evolving constantly. Experts in Educational Sciences are directly involved in developing their own skills to be competent and able to meet the challenges of a socio-economic environment in a continuous process of change.

Inclusive education is one of the most sensitive ongoing issues, because not all children enjoy an education experience that enables them to develop to their full potential [1-2]. Inclusion in the UK context means primarily inclusion of those with physical or learning disadvantage - whilst the thrust here is also about equality of educational opportunity in re the socio-economic circumstances of the child. Inclusion in education means if it means anything is respect for the diversity of all our children, and if this is to be realised must include several changes of substance in terms of educational content, pedagogical and

\footnotetext{
*Corresponding author: alina.mag@ulbsibiu.ro
} 
didactical approach, the structure of the education system and educational strategies. Although many programs and projects are implemented to enable inclusion of children with different special needs in mainstream schools, in many countries, the results are often positive, but dissemination of results and best practices is not systematically undertaken.

\section{Problem statement}

Children can change the world and education can change the way children perceive the world. Inclusion refers to all children, because inclusive education is one in which all children have access to quality education in an inclusive environment that provides three components:

- all children mean "children with disabilities, gifted children, homeless children, children belonging to nomadic groups, children belonging to linguistic minorities, ethnic or cultural, children with HIV or belonging to any other vulnerable groups" per Salamanca's Declaration (1994);

- quality education - means creating real opportunities to achieve success in the learning experience; in other words, the quality of education is not measured in terms of performance, graduation, infrastructure, technology and comfort, but the system capacity, the school and the teacher to create learning opportunities for every child;

- inclusive environment - which means that environment is welcome, protect and educate all children, regardless of gender, physical, intellectual, economic, linguistic or other characteristics (UNESCO).

Inclusive education is one of the top challenges in today's world, and whilst educational systems make efforts to become more inclusive, new teachers must be developed to be more inclusive in their future practice. University teachers involved in Education Studies arguably must address this in the theory and practice that they deliver on Teacher Training courses.

Nowadays Romania is facing huge economic and political crises. The level of the economic stress is high, affecting both adults and children. It is therefore appropriate to explore the conditions of inclusive education in Romania today and ask how far the current anxiety about children's rights is justified - and to ask ourselves: How can university teachers develop their own competencies to become truly inclusive? Is this theme a current pressing priority for their own training? These important questions were investigated in a university from Romania. The attitudes, opinions and lived experiences of inclusive education of future teachers were investigated and this research is focused on the opportunities created by listening to their opinions and the challenge is to harness their richness to produce better solutions. The vision of an expert in education from London Metropolitan University, United Kingdom was a real support during the study.

\section{Theoretical foundation and related literature}

Recently we have seen innovations in the focus of research, as political moves that challenge the ways different children have been excluded and silenced [3-4]. Inclusive education is a child's right, not a privilege. The amount of current attention given to children and to childhood is unprecedented [5]. Inclusion promotes quality and equitable education for all, without exclusion, including those who may be potentially marginalized by learning need or social position. In a world affected by financial crises, attitudes about children's needs are very important.

Inclusive education is now firmly established as the main policy imperative with respect to children who have special education needs or disabilities. It is championed to remove 
barriers, improve outcomes and remove discrimination. Inclusion is however, a complex and contested concept and its manifestations in practice are many and various [6].

Recent studies demonstrated that if children's educational needs are not fulfilled in the first years of life, serious gaps will appear in their development [7-8]. The attitudes of adults, in all their different roles and relationships, affect children deeply. Children have been silenced and excluded in many ways, because they were underestimated. They have different needs or special needs, and they need inclusive education for a proper development. In fact, all children are born with sophisticated capacities and adults should not restrict or limit their potential. Educators should work with children in new ways driven by a rights perspective [5].

Politicians and the media debate today's children's educational needs. According to recent studies children's mental and emotional health depends on the efficiency of the relationships that adults construct with them from conception [9]. Parents and teachers are responsible for children's health and development and they should practice inclusive education. New studies into children's competencies from birth changed the vision on children's potential and needs [10]. In the century of change, adult's abilities are vital, such as supporting children's emotions, understanding stressful situations, developing relationships and communication skills, promoting critical and creative thinking and demonstrating empathy.

Inclusive education in Romania is based on several national documents like: the Constitution of Romania 1991; Law no. 53/1992 on special protection of disabled persons and Law no. 57 on the emplyoment of disabled persons (amended by Ordinance no. 47/1997, subsequently repealed by Ordinance no. 102/1999 on special protection and employment of disabled persons) and Education Law no. 84/1995. The main international documents for inclusive education are: World Declaration on Education for All (1990); CoE recommendations on coherent policy for the rehabilitation of persons with disabilities (1992); Standard rules on equalization of opportunities for persons with disabilities (1993); Declaration of World Conference on Special Education, Salamanca (UNESCO, 1994). All efforts inside the educational departments in different universities all over the world relay on these important documents.

Educational partnership is one of the key words of the contemporary pedagogy [11]. Partnerships are indispensable for a qualitative inclusive education. Anxieties among teachers because of the financial crisis, too many changes brought by educational reform, anxieties about parents' involvement in education, the growing number of children with behavioural and emotional disorders are important issues in today's education in our country. The efforts to create an inclusive environment for Romanian children are still a challenge [1].

\section{Purpose of the study}

In this paper, we intend to assess what university teachers from the Teacher Training Department of "Lucian Blaga" University from Sibiu, Romania, consider to be their key efforts to support inclusive education, at the beginning of this year. The key argument of this study is that inclusive education is a real and urgent need for our educational system, starting with early childhood and ending with university's education. The main factors of inclusion are: the teachers, the colleagues in the classroom or school and the school environment. It's obvious that inclusion depends largely on the teachers' training, on their attitude and on their way to report to the children with SEN, as well as on the teaching strategies used.

The aim of this investigation is to find new ways of international support, of collaboration and good practice, with the professional involvement of experts in university 
education from London Metropolitan University, so that we can take new measures to create a professional environment for all our students that will become the next generation of teachers at all levels.

\section{Methodology}

The study started with a systematic review of current guidelines in teacher training from Inclusive Education frameworks available nationally and internationally and of the competencies required in this area for university teachers today. The next step was an analyse of the current situation and needs for training in inclusive education in the Romanian Teacher Training Department. In recognition of the importance of professional learning we conducted a survey with open questions to identify teachers' ongoing professional learning needs about inclusive education. This is a big challenge for all but it is an opportunity to advance the Teacher Training Department as a change factor that promotes dialogue and participation, making possible well-being through an education of quality for all without exception, for the commitment of the community. We also used focus group as a technique to collect data from 20 university teachers in our Department in Sibiu, Romania. They were voluntarily involved in the study. The survey was built to reveal the next professional concerns:

- What is inclusive education in the vision of the teachers from the Teacher Training Department?

- How do university teachers specialised in education made the distinction between inclusive education as a right and inclusive education as efficacy in their own practice?

- How do university teachers develop their own competencies in the field of inclusive education?

- What are the benefits of inclusive education for their perspectives?

We examined the personal arguments and the evidence presented for their personal professional development in this area, having the support and expertise for analysing the findings from London Metropolitan University, United Kingdom.

\section{Findings}

Evidence shows that the quality of teaching has one of the largest impacts on students learning. Building teaching excellence through pre-service and in-service training is central to making educational settings more inclusive. The teachers involved in the study started with a swot analysis of the inclusive education in Romania revealed that this is a real challenge for our staff. Findings revealed that the main strong points are: children with soft and medium disabilities are included; intervention team; intervention instruments; efficient learning strategies: individualised learning, cooperative learning; partnership with family and local community; initial and continuous development of teachers. The low points are: discontinuities in educational policies and incoherence in reforms application; having a certificate of SEN; insufficient number of support teachers and hours for activities with children with SEN; a great number of children in the class; different assessment in primary school and gymnasium; national exams are not different. We also evaluated the opportunities - Romania Integration in European Union, accessing European money through national and international projects, teacher continuous development - and the main barriers: stereotypes and misjudgement; financial resources crises; infrastructure and inadequate material resources.

This radiography of the Romanian inclusion was analysed by the 20 university teachers from the Teacher Training Department. They consider that inclusive education is a serious 
priority and they admit that most of their courses and seminars need continue improvement in this area and their interest to develop new skills is high. Their motivation to develop the opportunities, to reduce the low points and to fight the barriers starts with their own preparation to promote inclusive education. During the focus group, the university teachers were interviewed with all the questions mentioned, so they offered an objective overview of their perspectives, efforts, actions and plans to develop their competencies in this area. We will present the findings in a synthetic perspective, to each question.

At the first question, they admit that inclusion requires a large vision and specific competencies for all teachers. Now teachers need to know that diversity is present in the classroom, and that they should attend to learners with a range of diverse needs. In this frame, it is imperative to develop the following professional aptitudes: researcher, strategic and resilient. They identified important educational aspects that every teacher needs to be inclusive: equality; promoting the same opportunities for all, quality; offering functional and meaningful learning and equity; responding to special educational needs.

At the second question part of the teachers report that a lack of teacher training in facilitating the learning of students with disabilities is a barrier to individuals being able to succeed in education. Knowing students' rights, it's not sufficient. Teachers' educational efforts are valued by the student success in time, not just in school. As with all professional learning activities, it is important to stay up-to-date with current thinking and keep building professional expertise as new research and knowledge emerges.

At the third question, the teachers presented all their actions and plans to develop the skills to provide an inclusive environment, where every student can learn and achieve their full potential. The last years' most of them were engaged in relevant professional learning activities to prepare their own development in this area: research, observation and practice, training courses and seminars, conferences, workshops, an important project about mentoring in inclusive education managed by one of our professor in which four colleagues were trainers in inclusive education. Some of them already published relevant studies about inclusive education.

Professional learning is most effective when it is relevant, collaborative and future focused, and when it supports teachers to reflect on, question and consciously improve their skills. According to the teachers interviewed, they also need to have high expectations for all (inclusive vision), develop inclusive projects including diverse teaching strategies and support systems (inclusive practices) and participate in a collective work. The group investigated from the Teacher Training Department proposed the development of a new master program about Interventions in inclusive school.

The last question proved the benefits of inclusive education per the university teachers involved in the study. All children benefit from inclusive education, because it allows them to: develop individual strengths and gifts, with high and appropriate expectations for each child, involve their parents in their education, foster a school culture of respect and belonging, inclusive education provides opportunities to learn about and accept individual differences, lessening the impact of harassment and bullying, develop friendships with a wide variety of other children, each with their own individual needs and abilities and positively affect both their school and community to appreciate diversity and inclusion on a broader level. The inclusive teacher has a holistic educational view with strong skills and experience to participate in diverse contexts.

Findings were analysed together with two London experts to find new ways of international support, of collaboration and good practice that can help us improve our perspectives. A creative way that we approached this in one UKHE setting was to develop a first-year undergraduate module for Education Studies students that modelled inclusive practice in learning, teaching and assessment. 
The module was creative and emancipatory, designed to challenge and engage ALL the participants, including those with their own Specific Learning Needs (typically this included students with Dyslexia) and those who had experienced previous educational rebuff because of socio-economic status (this included what we term 'non-traditional' students and those who had been 'looked after'/in care).

The module "Becoming an Educationist" was delivered mainly in 'workshop' mode, with role play and simulations, draw-to-learn and music workshops, real qualitative research, student-led 'performances', active-, question- and project based learning - and choice - for example, choice about which projects to submit for the final assessment. Students were required to 'blog' their learning as part of reflective practice - and to develop a writing habit that thus also improved their formal academic writing.

The goal was to develop student self-efficacy at the same time as expanding their notion of what education was, what it could be and how it could promote inclusion and equality for all. The graduates from this module reported increased self-confidence and increased academic success. In a succeeding Becoming a Teacher module, they all cited "Becoming an Educationist" as a role model of good practice to harness in their own future teaching practice. Ideally, we would have such a module at every level of an Education Studies student's under- and postgraduate programmes. Inclusivity has to part of a trainee teacher's own tuition if it is to be realised in a future teacher's practice.

\section{Conclusions}

Children need to be listened to, valued and re-evaluated. Their rights should be respected, no matter what economic issues affects adult's lives. Children need to be respected by parents, carers and professionals, but this respect is shaped by their attitudes towards children - and their own experiences of teaching, learning and assessment. Certain attitudes and practices affect many children in ways that are not beneficial, and which can harm or restrict them. The language and actions of power and regulation held by adults in making and overseeing children's lives has been explored through the ways in which research, thinking and practice around inclusive education is reconstructing education and children in new ways.

It is a fact, every educational system in the world needs to improve and work towards the best results for all. By respecting children's educational needs, and developing empowering curricula and pedagogy, we have the chance to regain essential universal values for peace, justice and welfare. We must reach out with empathy to those next to us, listen to children, and fight for justice, for principles and for values. The study had a significant impact in our teachers' motivation to practice inclusive education. We need to increase attention to our professional development as a factor that can contribute to a healthy society and to a better live for children in Romania.

\section{References}

1. T. Vrasmas, Invatamantul integrat si/sau incluziv (Aramis Pub., Bucharest, 2001)

2. D. Mara, Strategii didactice in educatia incluziva, 2nd Ed. (Didactic and Pedagogical Pub, Bucharest, 2009)

3. C. Smith, L. Strick, Dizabilitati legate de invatare, explicate de la A la Z, (Aramis Pub., Bucharest, 2011)

4. A. Ghergut, Psihopedagogia persoanelor cu cerinte speciale. Strategii de educatie integrata (Polirom Pub., Iasi, 2001)

5. P. Jones, Rethinking childhood. Attitudes in Contemporary Society, New childhoods (Continuum, New York, 2009) 
6. G. Lindsay, Inclusive education: a critical perspective, British Journal of Special Education 30(1), 3-12 (2003)

7. American Psychiatric Association, Diagnostic and Statistical Manual of Mental Disorders, 5th Ed., DSM-5 (APA, Washington DC, 2013)

8. A. Rosan, (coord.), Psihopedagogie speciala Metode de evaluare si interventie (Polirom Pub., Iasi, 2015)

9. C. Cable, L. Miller, Working with Children in the Early Years. 2nd Ed. (Routledge Taylor Francis Group, London and New York, 2010)

10. J. Johnson, Positive and trusting relationships with children in Early Years Settings (Learning Matters, Great Britain, 2010)

11. D. Mara, Partnership in Inclusive Education, Int. Journal of University Teaching and Faculty Development, 5(1), (Nova Science Publishers, 2014) 